\title{
Evaluation of the Knowledge and Attitudes of Dental Health Care Workers Regarding the New Coronavirus Disease-2019 Outbreak
}

\author{
Diş Hekimliği Sağlık Çalışanlarının Koronavirüs Hastalığı-2019 \\ Salgınına Karşı Bilgi Düzeyi ve Davranışlarının Değerlendirilmesi \\ (D) Ahu Dikilitaş ${ }^{1}$, (1) Fatih Karaaslan ${ }^{1}$, (1) Şehrazat Evirgen ${ }^{2}$ \\ ${ }^{1}$ Uşak University Faculty of Dentistry, Department of Periodontology, Uşak, Turkey \\ ${ }^{2}$ Uşak University Faculty of Dentistry, Department of Oral and Maxillofacial Radiology, Uşak, Turkey
}

Keywords

Dentistry, coronavirus, infections, knowledge, attitudes

Anahtar Kelimeler

Diş hekimliği, koronavirüs, enfeksiyon, bilgi, davranışlar

Received/Geliş Tarihi : 11.11.2020

Accepted/Kabul Tarihi : 23.12.2020

doi:10.4274/meandros.galenos.2020.96636

Address for Correspondence/Yazışma Adresi: Ahu Dikilitaş DDS, MSc, PhD. Assistant Prof, Uşak University Faculty of Dentistry, Department of Periodontology, Uşak, Turkey Phone : +90 5063569500

E-mail : ahu.dikilitas@usak.edu.tr

ORCID ID: orcid.org/0000-0003-4130-2526

(C) Meandros Medical and Dental Journal, Published by Galenos Publishing House.

This is article distributed under the terms of the Creative Commons Attribution NonCommercial 4.0

International Licence (CC BY-NC 4.0).

\begin{abstract}
Objective: Coronavirus disease-2019 (COVID-19) is contagious through respiratory droplets, close contact and aerosols emitted from high-end instruments. Dentists are at high risk for infection and have become carriers of the disease. Thus, dental health professionals should have sufficient knowledge and a high level of awareness on this issue. This study aimed to investigate the levels of knowledge and awareness about COVID-19 among dentists, students of dentistry and dental nurses.

Materials and Methods: This study included 124 dentists, 122 students of dentistry and 128 nurses. A closed-ended questionnaire was developed with the help of the existing literature. The questionnaire, containing ten questions, was divided into three parts.

Results: Dentists, nurses and students of dentistry had adequate information regarding COVID-19. It was determined that all the participating dentists (100\%) and nurses (100\%) and most students of dentistry (97.5\%) felt threatened by being exposed to COVID-19 infection. A significantly higher proportion of dentists $(58.9 \%)$ and clinical students (55.7\%) compared to nurses (9.4\%) believed that using protective equipment during dental practice will not protect them against COVID-19 infection.

Conclusion: Dental health care workers should be trained in the prevention and control of COVID-19, and they should regularly renew these skills to protect themselves against new infections that may occur in the future.
\end{abstract}

Öz

Amaç: Koronavirüs hastalığı-2019 (COVID-19) solunum damlacığı, yakın temas ve yüksek hızlı aletlerden yayılan son aerosoller yoluyla bulaşıcıdır, diş hekimleri enfeksiyon için büyük risk altındadır ve hastalığın taşıyıcıları haline gelmişlerdir. Bu nedenle diş hekimliği sağlık çalışanlarının bu konuda yeterli bilgiye sahip olması ve farkındalık yaratması gerekmektedir. Bu çalışmanın amacı, diş hekimleri, diş hekimliği klinik öğrencileri ve diş hekimliği hemşirelerinin COVID-19 hakkındaki bilgi ve farkındalık düzeylerini araştırmaktır. 
Gereç ve Yöntemler: Bu çalışmaya 124 diş hekimi, 122 diş hekimliği klinik öğrencisi ve 128 diş hekimliği hemşiresi dahil edildi. Mevcut literatür yardımıyla kapalı uçlu bir anket geliştirildi. On soru içeren anket üç bölüme ayrıldı.

Bulgular: Diş hekimleri, hemşireler ve klinik öğrencileri COVID-19 hakkında yeterli bilgiye sahiptir. Tüm diş hekimleri (\%100) ve hemşirelerin (\%100) ve çoğu klinik öğrencisinin (\%97,5) COVID-19 enfeksiyonuna karşı tehdit altında hissettiği belirlendi. Diş hekimi muayenesi sırasında koruyucu ekipman kullanmanın COVID-19 enfeksiyonuna karşı korumayacağını düşünen diş hekimleri $(\% 58,9)$ ve klinik öğrencilerinin oranı hemşirelere göre istatistiksel olarak daha yüksekti $(\% 9,4)$.

Sonuç: Diş hekimliği sağlık çalsşanları, COVID-19'un önlenmesi ve kontrolü konusunda eğitilmeli ve gelecekte oluşabilecek yeni enfeksiyonlara karşı korunmak için bu becerileri düzenli olarak yenilemelidirler.

\section{Introduction}

In 2019, an outbreak of a novel coronavirus, named coronavirus disease-2019 (COVID-19), appeared in Wuhan, China (1). This new coronavirus belongs to the family of single-stranded RNA viruses known as Coronaviridae (2). This family of viruses first appeared as severe acute respiratory syndrome coronavirus (SARS-CoV) in 2002 and later as Middle East respiratory syndrome coronavirus (MERS-CoV) in 2012. The new coronavirus has a close resemblance to other ß-coronaviruses, such as SARS-CoV and MERS-CoV (3). Although SARS-CoV-2 is the novel coronavirus's scientific name, the disease it causes is popularly referred to as COVID-19 (4-6).

COVID-19 has spread globally, being labeled a public health crisis and pandemic by the World Health Organization (WHO) (7). The governments of China, Italy and other nations have restricted the constant movement of workers outside their homes and required social distancing and the use of protective masks and gloves to "flatten the curve" of infection by minimizing contact with individuals who serve as carriers $(7,8)$.

According to recent studies and to China National Health Commission data, the rate of serious cases among all patients with COVID-19 in China stands at around $15-25 \%(9,10)$. While the majority of patients experience fever and dry cough, some have also been reported to have other atypical symptoms, such as shortness of breath, fatigue, confusion, headaches, sore throat, diarrhea and vomiting $(9,11)$. Although SARS-CoV-2 is known to be highly contagious when patients are most symptomatic, it has been reported that the incubation period can range from 0 to 24 days, so transmission may occur before any symptoms are seen $(9,12)$.

Given the widespread contagion of SARS-CoV-2 and reports that health workers are infected, it has been reported that dentists are at high risk for hospital infection and may be potential carriers of the disease. Additionally, it has been shown that dental patients could potentially be exposed to cross contamination if adequate precautions are not taken (4). The saliva, secretions and blood of patients who cough and sneeze with high-speed hand tools or ultrasonic instruments in their mouth during dental treatment cause the virus to be aerosolized and spread through the environment. Thus, the dental instruments in the clinical environment become contaminated with various pathogenic microorganisms. After this, infection occurs as a result of sharp tool injury or direct contact of the mucosa with contaminated hands $(13,14)$. Due to the unique feature of dental treatments that result in the production of large numbers of droplets and aerosols, standard preservatives used in daily clinical trials are not effective enough to prevent COVID-19, especially when the disease is in the incubation process (14). As the number of cases and deaths worldwide continues to increase, prevention of disease, identification of sick individuals and appropriate management of this process by health care workers are needed to prevent further spread.

It has been reported that every patient who comes to the clinic needs to be questioned about their temperature, whether they have travelled abroad and whether they have met with someone from abroad $(15,16)$. Likewise, the use of antimicrobial mouthwash before processing and avoiding processes that may cause coughing, such as intraoral X-rays, and aerosolproducing processes such as using high-speed hand tools, should be delayed as much as possible $(13,17-$ 19). The information levels and behaviors of dentists, dental clinic students who are in close contact with patients and dental nurses who are involved in all kinds of procedures of interest to the patient are very important in order to prevent the spread of the 
disease in the face of such a pandemic. In order to prevent the spread of the disease to other patients through cross-infection, it is very important for health workers to know how to protect both the patient and themselves. The purpose of this study was to determine the level of knowledge and behavior of dentists, nurses and dental clinical students regarding the COVID-19 pandemic.

\section{Materials and Methods}

This study ran at the Faculty of Dentistry of the University of Uşak. It was performed pursuant to the Helsinki Declaration, and ethical permission was taken from the Ministry of Health (2020-07-01T0655-00) and the Local Ethics Committee of Usak University (decision no: 27-12-16, date: 22.07.2020). All participiants provided informed consent. In this study, COVID-19 knowledge level and behavior of dental health care workers were evaluated.

The study included individuals who responded online to questions about COVID-19. The sample consisted of 124 dentists, 122 dentistry clinical students and 128 nurses. A closed-ended questionnaire was developed by the researchers and guided by the existing literature. The questionnaire contained 13 questions that measured the knowledge and attitude of dental health care workers in regard to the COVID-19 pandemic.

In order to prevent the spread of the disease, the study was conducted online, and participants were asked 10 questions in 3 sections:

1. Source of information about COVID-19,

2. Knowledge about COVID-19 (mortality rate, incubation period, individuals at risk, symptoms and prevention techniques),

3. Attitudes about COVID-19.

\section{Statistical Analysis}

Data analysis was performed using the software Statistical Package for the Social Science (SPSS) version 17.0, and statistical significance level was set at 0.05. Demographic information was evaluated using descriptive statistical analysis. Chi-square tests were used to compare general knowledge levels and attitudes of dental health care workers toward COVID-19.

The G*Power 3.1 package program was utilized to define the adequate specimen dimension. When evaluating the specimen size, type 1 error $(\alpha)=0.05$, effect size $=0.293$ and test power $(1-\beta)=0.90$ were used. Conclusion of the evaluation, the specimen volume was defined as a minimum of 172 individuals.

\section{Results}

Data were collected from 374 patients and the ages ranged from 18 to 59 years. The study population comprised 257 (68.70\%) women and 117 (31.30\%) men. Demographic information (gender and age) of individuals according to each group is shown in Table 1 . In this study, $33.16 \%$ of the participants are dentists, $34.22 \%$ are nurses and $32.62 \%$ are dentistry clinic students.

The sources of information about COVID-19 for each group are shown in Table 2. There was a statistically meaningful difference among the groups. Although dentists and nurses tend to rely on social media and the Ministry of Health of the Republic of Turkey, dental clinic students rely on all resources to gather information. The proportion of dentists and nurses who answered "Ministry of Health," is significantly higher than the proportion of clinical students who did.

Table 3 shows the level of knowledge about COVID-19 among the three groups. There were meaningful differences among groups in terms of information about mortality proportion and symptoms COVID-19. There were no meaningful differences among groups in terms of information about incubation period, individuals at risk or ways to prevent the spread of COVID-19.

\begin{tabular}{|c|c|c|c|c|c|c|c|c|c|c|}
\hline \multirow{3}{*}{$\begin{array}{l}\text { Healthcare } \\
\text { workers }\end{array}$} & \multicolumn{4}{|c|}{ Gender } & \multicolumn{6}{|l|}{ Age } \\
\hline & \multicolumn{2}{|c|}{ Male } & \multicolumn{2}{|c|}{ Female } & \multicolumn{2}{|c|}{$18-25$} & \multicolumn{2}{|c|}{$26-39$} & \multicolumn{2}{|c|}{$40-59$} \\
\hline & $n$ & $\%$ & $n$ & $\%$ & $n$ & $\%$ & $n$ & $\%$ & $n$ & $\%$ \\
\hline Dentist & 67 & 54.0 & 57 & 46.0 & 17 & 13.7 & 86 & 69.4 & 21 & 16.9 \\
\hline Clinical student & 71 & 58.2 & 51 & 41.8 & 122 & 100 & - & - & - & - \\
\hline Nurse & 119 & 93.0 & 9 & 7.0 & 6 & 4.7 & 35 & 27.3 & 87 & 68 \\
\hline
\end{tabular}


Dentists (39.7\%) and clinical students (37.5\%) were significantly more likely to answer the mortality rate question correctly compared to. The percentage of dentists and nurses who answered the question about symptoms of COVID-19 correctly was significantly higher than that of clinical students.

Likewise, participants' attitudes toward COVID-19 are shown in Table 4. There were meaningful

Table 2. Sources of information about coronavirus disease-2019

\begin{tabular}{|c|c|c|c|c|}
\hline \multirow{2}{*}{ Sources information } & \multirow{2}{*}{ n (\%) } & \multicolumn{3}{|c|}{ Healthcare workers } \\
\hline & & Dentist & Nurse & Clinical students \\
\hline \multirow{2}{*}{ Mass media } & $\mathrm{n}$ & 18 & 18 & 5 \\
\hline & $\%$ & 43.9 & 43.9 & 12.2 \\
\hline \multirow{2}{*}{ Social media } & $\mathrm{n}$ & 65 & 45 & 30 \\
\hline & $\%$ & 46.4 & 32.1 & 21.4 \\
\hline \multirow{2}{*}{ Ministry of health } & $\mathrm{n}$ & 39 & 62 & 12 \\
\hline & $\%$ & 34.5 & 54.9 & 10.6 \\
\hline \multirow[b]{2}{*}{ Public } & $n$ & 2 & 3 & - \\
\hline & $\%$ & 40 & 60 & - \\
\hline \multirow{2}{*}{ Total } & $\mathrm{n}$ & 124 & 128 & 122 \\
\hline & $\%$ & 33.2 & 34.2 & 32.6 \\
\hline
\end{tabular}

Table 3. Knowledge about coronavirus disease-2019

\begin{tabular}{|c|c|c|c|c|c|c|c|c|}
\hline \multirow{3}{*}{ Questions and answers } & \multirow{3}{*}{ Answer results } & \multicolumn{6}{|c|}{ Healthcare workers } & \multirow{3}{*}{$\mathbf{p}$} \\
\hline & & \multicolumn{2}{|c|}{ Dentist } & \multicolumn{2}{|c|}{ Nurse } & \multicolumn{2}{|c|}{ Clinical students } & \\
\hline & & $n$ & $\%$ & $n$ & $\%$ & $n$ & $\%$ & \\
\hline \multirow{2}{*}{$\begin{array}{l}\text { What is the COVID-19 } \\
\text { mortality rate? } \\
(0.39 \%-4.05 \%)\end{array}$} & False & 35 & 23.3 & 77 & 51.3 & 38 & 25.3 & \multirow[b]{2}{*}{$0.001^{*}$} \\
\hline & True & 89 & 39.7 & 51 & 22.8 & 84 & 37.5 & \\
\hline \multirow{2}{*}{$\begin{array}{l}\text { What is the longest incubation } \\
\text { period of COVID-19? } \\
\text { ( } 21 \text { days) }\end{array}$} & False & 39 & 32.5 & 44 & 36.7 & 37 & 30.8 & \multirow{2}{*}{0.792} \\
\hline & True & 85 & 33.5 & 84 & 33.1 & 85 & 33.5 & \\
\hline \multirow{2}{*}{$\begin{array}{l}\text { Which individuals are at risk } \\
\text { for coronavirus? } \\
\text { (Health care workers, } \\
\text { indivudials who have } \\
\text { cardiovascular disease, elders) }\end{array}$} & False & 2 & 15.4 & 3 & 23.1 & 8 & 61.5 & \multirow[b]{2}{*}{0.069} \\
\hline & True & 122 & 33.8 & 125 & 34.6 & 114 & 31.6 & \\
\hline \multirow{2}{*}{$\begin{array}{l}\text { What are the ways to prevent } \\
\text { COVID-19 infection? } \\
\text { (Isolation, hand hygiene, } \\
\text { mask) }\end{array}$} & False & 10 & 43.5 & 3 & 13.0 & 10 & 43.5 & \multirow{2}{*}{0.087} \\
\hline & True & 114 & 32.5 & 125 & 35.6 & 112 & 31.9 & \\
\hline \multirow{2}{*}{$\begin{array}{l}\text { What are the symptoms of } \\
\text { COVID-19 infection in people? } \\
\text { (Fever and dry cough, } \\
\text { headaches and vomiting, loss } \\
\text { of taste and smell) }\end{array}$} & False & 11 & 24.4 & 3 & 6.7 & 31 & 68.9 & \multirow{2}{*}{$0.001^{*}$} \\
\hline & True & 113 & 34.3 & 125 & 38 & 91 & 27.7 & \\
\hline
\end{tabular}


differences among groups in terms of attitudes about feeling threatened, wearing personal preventive devices (PPE), treating infected patients and focusing on treatment condition when treating patients infected with COVID-19. All dentists (100\%) and nurses $(100 \%)$ and most clinical students (97.5\%) feel threatened by exposure to the virus. The proportion of dentists (58.9\%) and clinical students $(55.7 \%)$ who assume that applying PPE, such as glasses, gloves, face guards, masks and preventive clothing, during dental treatment will not prevent them versus COVID-19 disease is statistically higher than among nurses. The proportion of dentists (52.4\%) and nurses (51.6\%) who would treat an individual who has had COVID-19 and recovered is statistically higher than among clinical students (29.5\%). The proportion of dentists (34.7\%) focusing on therapy while curing a subject who has recovered from COVID-19 was significantly higher than among clinical students (21.3\%) and nurses (18\%) Table 4.

\section{Discussion}

The outbreak of the novel coronavirus has been declared a public health emergency of international concern by WHO. Infection control measures must be taken to prevent further spread of the virus and to help control the pandemic. Dental treatment involves exposure to blood and saliva in the patient's mouth, and the devices used are associated with aerosols, corresponding to a potentially high risk of crossinfection among dental health care professionals. Training on strict and effective infection control protocols and the development of a new behavior model are urgently needed in dentistry clinics in areas affected by COVID-19. At the same time, this research sought to determine the attitudes and behaviors of dental professionals in the face of the pandemic and to discover the deficiencies that need to be improved to reduce the spread of infection and the mortality rate.

Dentists and nurses received information about COVID-19 from the Ministry of Health and social media, while the majority of clinical students received information from social media. In Fatiregun et al. (20) and Albano et al. (21), it was reported that the main source of information was television. These differences can be explained by recent progress in internet technologies. Today, most educational materials and health messages are published online by health care providers, and information about

\begin{tabular}{|c|c|c|c|c|c|}
\hline Questions & Healthcare workers & $\begin{array}{l}\text { Yes } \\
\text { (n/\%) }\end{array}$ & $\begin{array}{l}\text { No } \\
(n / \%)\end{array}$ & $\begin{array}{l}\text { No idea } \\
\text { (n/\%) }\end{array}$ & $p$ \\
\hline \multirow{3}{*}{$\begin{array}{l}\text { Do you sense greater endangered by be exposed to } \\
\text { COVID-19 contaminations as a healthcare worker } \\
\text { than other people? }\end{array}$} & Dentist & $124 / 33.4 \%$ & $0 / 0$ & $0 / 0$ & \multirow{3}{*}{$0.037^{*}$} \\
\hline & Nurse & $128 / 35.5 \%$ & $0 / 0$ & $0 / 0$ & \\
\hline & Dental student & $119 / 32.1 \%$ & $1 / 100$ & $2 / 100$ & \\
\hline \multirow{3}{*}{$\begin{array}{l}\text { Do you think preventive devices such as glasses, } \\
\text { gloves, face guards and masks will prevent you from } \\
\text { COVID-19 diseases? }\end{array}$} & Dentist & $45 / 22.1 \%$ & $73 / 47.7 \%$ & $6 / 35.3 \%$ & \multirow{3}{*}{$0.001^{*}$} \\
\hline & Nurse & $110 / 53.9 \%$ & $12 / 7.8 \%$ & $6 / 35.3 \%$ & \\
\hline & Dental student & $49 / 24 \%$ & $68 / 44.4 \%$ & $5 / 29.4 \%$ & \\
\hline \multirow{3}{*}{$\begin{array}{l}\text { Would you want to treat an individual who have had } \\
\text { COVID-19 infection and cured? }\end{array}$} & Dentist & $65 / 38.9 \%$ & $47 / 29.9 \%$ & $12 / 24 \%$ & \multirow{3}{*}{$0.001^{*}$} \\
\hline & Nurse & $66 / 39.5 \%$ & $50 / 31.8 \%$ & $12 / 24 \%$ & \\
\hline & Dental student & $36 / 21.6 \%$ & $60 / 38.2 \%$ & $26 / 52 \%$ & \\
\hline \multirow{3}{*}{$\begin{array}{l}\text { When treating a patient with a COVID-19 infection } \\
\text { would you focus primarily on not being infected? }\end{array}$} & Dentist & $81 / 65.3 \%$ & $43 / 34.7 \%$ & $0 / 0 \%$ & \multirow{3}{*}{$0.001 *$} \\
\hline & Nurse & $105 / 82 \%$ & $23 / 18 \%$ & $0 / 0 \%$ & \\
\hline & Dental student & $96 / 78.7 \%$ & $26 / 21.3 \%$ & $0 / 0 \%$ & \\
\hline
\end{tabular}


COVID-19 is regularly provided on the Ministry of Health's website. In addition, while many dentists and nurses go to the Ministry of Health to obtain information, this rate is found to be very low among clinic students. This is likely due to changing patterns of acquiring information, as knowledge and skills increase over the years and older adults come to depend on public institutions.

Dentists, nurses and clinical students had adequate knowledge about COVID-19 (incubation period, individuals at risk and prevention techniques). Dentists' and clinical students' knowledge of the mortality rate of COVID-19 was significantly higher than that of nurses. In contrast, dentists' and nurses' knowledge of the symptoms of COVID-19 was significantly higher than that of clinical students. It is thought that dentists and clinical students who continue their education have a higher level of academic knowledge that focuses on details, such as the mortality rate, and that nurses who have been side-by-side with physicians in the clinic for many years are more alert to symptoms of the disease.

All dental health care workers sense greater endangered by be exposed to COVID-19 than individuals outside the health care field. COVID-19 is a new infection, and health workers have never experienced such a disease before. The nature of the dentistry profession requires that it is performed at close proximity to the patients, specifically face-toface and in the patient's oral cavity. It is also known that droplets released from infected individuals in dental clinics and aerosols released from electronic tools hang in the air for long periods of time. Due to the peculiar nature of dental treatment procedures and the increased media reporting that health workers are infected, dental health workers feel much more threatened.

Dentist and clinical students tend to assume that utilizes shield device, like as glasses, gloves, face guards, masks and preventive clothing, during dental treatment will not prevent them versus transmission. This is thought to be due to the fact that dentists and clinical students have to work in close contact with their patients, and not all of the protective clothing meets the necessary standards of protection and endurance. In contrast, nurses think that their protective equipment will protect them adequately. This may be because nurses do not have direct contact with patients and, as a result, they may feel more secure by maintaining adequate distance in addition to wearing protective equipment.

The proportion of dentists (52.4\%) and nurses (51.6\%) who want to treat an individual who has had COVID-19 and recovered was found to be low but significantly higher than for clinical students (29.5\%). Studies have reported that factors such as being female, the timing of infection, presence of supportive staff and status of family members are factors associated with being less willing to work in the event of a public health emergency, such as the flu (22). A study by Quereshi et al. (23), in which health workers' willingness to work during catastrophic disasters was evaluated, reported that $48 \%$ of the sample volunteered to work during the SARS outbreak.

In our study, volunteering to care for an infected patient was found to be similarly low, as in other studies. This is thought to be due to the lack of adequate protective equipment, inability to maintain adequate distance with their patients and having children waiting at home. Clinical students have lower willingness than other health care workers, likely due to their lack of professional experience, the unease of their parents and having never experienced such a situation before. A study by Shapira et al. (24) reported that, by increasing access to PPE, willingness to treat patients during such situations can be raised. Dental workers are in contact with droplets, aerosols and small, sharp instruments, and many health workers are unwilling to treat infected and recovered patients. Likewise, patients may not give accurate information about their illness due to the reluctance of health workers to treat them. This unethical situation could pose a serious public problem. The way to encourage clinicians to treat patients with infectious diseases is to improve their attitudes, not enact legal penalties. Changing attitudes can only be possible with improved knowledge and the creation of a safe environment.

Furthermore, $82 \%$ of nurses, $78.7 \%$ of clinical students and $65.3 \%$ of dentists talk that they concentrate on not contaminated themselves rather of providing therapy while healing a patient who has had COVID-19. The proportion of dentists focusing on treatment was significantly higher than the other two groups. A potential explanation is that dentists have more professional experience and that their control over patients and dental instruments is better, as well 
as their knowledge about the infection, compared to the other groups.

In this study, it was found that dental health care workers had sufficient knowledge of COVID-19 incubation periods, prevention routes and individuals at risk, and that dental students and nurses needed to increase their levels of knowledge about the mortality rate and symptoms. Dental health care workers tend to feel threatened when treating patients with COVID-19, and they often focused on not contaminated themselves, rather than treating the patients. They were also largely unwilling to treat patients who had been infected with COVID-19, even if they had recovered, and they did not have much trust in the ability of PPE to keep them safe. Additionally, dental health care workers were found to have received information about COVID-19 mostly from social media and the Ministry of Health.

There is currently no recommended treatment for coronavirus infections, but increased infection control measures are recommended for patients with COVID-19. Avoiding cross-infection is very important for health professionals who come in contact with mucous membranes, blood or bodily fluids (25). Therefore, COVID-19 infection is a very significant occupational hazard in dentistry.

\section{Conclusion}

Dental health care workers have sufficient knowledge about COVID-19 infection, and transmission and prevention methods are very important in the practice of infection control. The dentist should be very alert to the incubation period of the disease and postpone elective treatments until the risk of transmission has passed. Likewise, support should be planned to decrease the psychological influence of realized infection jeopardy by increasing access to equipment to protect dental health care workers. These supports can be in the form of training, improving morale, providing counseling and offering incentives. On the other hand, there is also a need to evaluate professional development programs by the Ministry of Health to identify gaps and adopt best practices. In the same context, dental health care workers should be encouraged to visit official websites to seek information on health-related issues, and the Ministry of Health's website should also be kept up-to-date.

\section{Ethics}

Ethics Committee Approval: This study ran at the Faculty of Dentistry of the University of Uşak. It was performed pursuant to the Helsinki Declaration, and ethical permission was taken from the Ministry of Health (202007-01T06-55-00) and the Local Ethics Committee of Usak University (decision no: 27-12-16, date: 22.07.2020).

Informed Consent: All participiants provided informed consent.

Peer-review: Externally and internally peer-reviewed.

\section{Authorship Contributions}

Concept: A.D., Design: A.D., F.K., Supervision: Ş.E., Data Collection or Processing: A.D., F.K., Analysis or Interpretation: Ş.E., F.K., Literature Search: Ş.E., A.D., Critical Review: A.D., Writing: Ş.E., A.D.

Conflict of Interest: No conflict of interest was declared by the authors.

Financial Disclosure: The authors declared that this study received no financial support.

\section{References}

1. Spagnuolo G, De Vito D, Rengo S, Tatullo M. COVID-19 outbreak: An overview on dentistry. Int J Environ Res Public Health 2020; 17: 2094.

2. Gorbalenya AE, Baker SC, Baric RS, Groot RJ, Drosten C, Gulyaeva $A A$, et al. The species Severe acute respiratory syndrome-related coronavirus: classifying 2019-nCoV and naming it SARS-CoV-2. Nat Microbiol 2020; 2: 1-9.

3. Wax RS, Christian MD. Practical recommendations for critical care and anesthesiology teams caring for novel coronavirus (2019-nCoV) patients. Can J Anaesth 2020; 67: 568-76.

4. Ather A, Patel B, Ruparel NB, Diogenes A, Hargreaves KM. Coronavirus disease 19 (COVID-19): Implications for clinical dental care. J Endod 2020; 46: 584-95.

5. Zhu N, Zhang D, Wang W, Li X, Yang B, Song J, et al. A novel coronavirus from patients with pneumonia in China, 2019. N Engl J Med 2020; 382: 727-33.

6. Gorbalenya AE, Baker SC, Baric RS, de Groot R, Drosten G, Gulyaeva AA, et al. Severe acute respiratory syndrome-related coronavirus: The species and its viruses - a statement of the Coronavirus Study Group. bioRxiv 2020: 1-15.

7. Sohrabi C, Alsafi Z, O'Neill N, Khan M, Kerwan A, Al-Jabir A, et al. World Health Organization declares global emergency: A review of the 2019 novel coronavirus (COVID-19). Int J Surg 2020; 76: 71-6.

8. Li R, Pei S, Chen B, Song Y, Zhang T, Yang W, et al. Substantial undocumented infection facilitates the rapid dissemination of novel coronavirus (SARS-CoV-2). Science 2020; 368: 489-93.

9. Guan WJ, Ni ZY, Hu Y, Liang WH, Ou CQ, He JX, et al. Clinical characteristics of 2019 novel coronavirus infection in China. medRxiv 2020. doi:10.1101/2020.1102.1106.20020974. 
10. Yang Y, Lu Q, Liu M, Wang Y, Zhang A, Jalali N, et al. Epidemiological and clinical features of the 2019 novel coronavirus outbreak in China. medRxiv 2020. doi:10.1101/2020.1102 .1110.20021675.

11. Yu T, Zhang X, Zhang L. Epidemiological and clinical characteristics of 99 cases of 2019 novel coronavirus pneumonia in Wuhan, China: a descriptive study. Lancet 2020; 395: 507-13.

12. Rothe C, Schunk M, Sothmann P, Bretzel G, Froeschl G, Wallrauch C, et al. Transmission of 2019-nCoV infection from an asymptomatic contact in Germany. N Engl J Med 2020; 382: 970-1.

13. Kohn WG, Collins AS, Cleveland JL, Harte JA, Eklund KJ, Malvitz DM. Centers for disease control and prevention (CDC). Guidelines for infection control in dental health-care settings--2003. MMWR Recomm Rep 2003; 52: 1-61.

14. Meng L, Hua F, Bian Z. Coronavirus disease 2019 (COVID-19): Emerging and future challenges for dental and oral medicine. J Dent Res 2020; 99: 481-7.

15. Li RW, Leung KW, Sun FC, Samaranayake LP. Severe acute respiratory syndrome (SARS) and the GDP. Part II: implications for GDPs. Br Dent J 2004; 197: 130-4.

16. Samaranayake LP, Peiris M. Severe acute respiratory syndrome and dentistry: a retrospective view. J Am Dent Assoc 2004; 135: 1292-302.

17. World Health Organization. Clinical management of severe acute respiratory infection when novel coronavirus (2019-nCoV) infection is suspected: interim guidance, 2020. https://www. who.int/publications-detail/clinical-management-of-severeacute-respiratory-infection-when-novel-coronavirus-(ncov)infection-is-suspected
18. Marui VC, Souto MLS, Rovai ES, Romito GA, Chambrone L, Pannuti CM. Efficacy of preprocedural mouthrinses in the reduction of microorganisms in aerosol: A systematic review. J Am Dent Assoc 2019; 150: 1015-26.

19. Vandenberghe $B$, Jacobs $R$, Bosmans $H$. Modern dental imaging: a review of the current technology and clinical applications in dental practice. Eur Radiol 2010; 20: 2637-55.

20. Fatiregun $A A$, Olowookere $S A$, Oyebade AO. Pandemic Influenza $A$ (H1N1): knowledge among senior health workers at a secondary health care institution in Southwest, Nigeria. Afr Health Sci 2011; 11: 171-5.

21. Albano L, Matuozzo A, Marinelli P, Di Giuseppe G. Knowledge, attitudes and behaviour of hospital health-care workers regarding influenza $A / H 1 N 1$ : A cross sectional survey. BMC Infect Dis 2014; 14: 208.

22. Khan A, Johani MA. Level of willingness to report to work during a pandemic among the emergency department health care professionals. Asian Journal of Medical Sciences 2014; 5: 58-62.

23. Qureshi K, Gershon RR, Sherman MF, Straub T, Gebbie E, McCollum $\mathrm{M}$, et al. Health care workers' ability and willingness to report to duty during catastrophic disasters. J Urban Health 2005; 82: 378-88.

24. Shapira Y, Marganitt B, Roziner I, Shochet T, Bar Y, Shemer J. Willingness of staff to report to their hospital duties following an unconventional missile attack: a state-wide survey. Isr J Med Sci 1991; 27: 704-11.

25. Keşkek ŞÖ, Erdoğan H. COVID-19: A current brief review. Acta Medica Alanya 2020; 4: 197-202. 